\title{
Enhancing the career capabilities of NEET youth in Hong Kong: an experience-driven framework
}

\author{
Xuebing Su' ${ }^{1} \cdot$ Victor Wong ${ }^{2}(\mathbb{C}$
}

Received: 25 January 2021 / Accepted: 28 January 2022 / Published online: 12 February 2022

(c) The Author(s), under exclusive licence to Springer Nature B.V. 2022

\begin{abstract}
Inspired by Amartya Sen's conceptualization of capability, this article examined how the introduction of an experience-driven (ED) framework into the capability approach helps inform the delivery of a career support service project targeted at youth aged 15-21, who are not in education, employment or training (NEET youth) with difficulties to develop their career capabilities. Based on a thematic analysis of ten individual interview transcripts collected from five career practitioners and five ex-users, the study discussed four interlocking domains of experiences and experience-driven career interventions for enhancing youth's capabilities to aspire and realize aspirations with a transition from the zone of proximal development to the zone of aspired development, namely, recognition, exposures, self-growth and transferability. We recommended further research studies on evaluating the effectiveness of using the ED framework for applying the capability approach to strengthening the career capabilities of service users characterized by diversity and vulnerability in different service settings.
\end{abstract}

Keywords Capability approach $\cdot$ NEET youth $\cdot$ Recognition

\section{Résumé}

\section{Améliorer les capacités de carrière des jeunes NEET à Hong Kong: un cadre axé sur l'expérience.}

Inspiré par la conceptualisation de la capacité d'Amartya Sen, cet article a examiné comment l'introduction d'un cadre axé sur l'expérience (ED) dans l'approche de la capacité aide à éclairer la prestation d'un projet de service de soutien à la car-

Victor Wong

vicwong@hkbu.edu.hk

Xuebing $\mathrm{Su}$

sabrina-xuebing.su@polyu.edu.hk

1 Department of Applied Social Sciences, The Hong Kong Polytechnic University, 11 Yuk Choi Road, Hung Hom, Kowloon, Hong Kong

2 Department of Social Work, Hong Kong Baptist University, 15 Baptist University Road, Kowloon Tong, Hong Kong 
rière destiné aux jeunes âgés de 15 à 21 ans, qui ne sont pas aux études., à l'emploi ou à la formation (jeunes NEET) ayant des difficultés à développer leurs capacités professionnelles. Sur la base d'une analyse thématique de dix transcriptions d'entretiens individuels recueillies auprès de cinq praticiens de carrière et de cinq anciens utilisateurs, l'étude a examiné quatre domaines interdépendants d'expériences et d'interventions de carrière axées sur l'expérience pour améliorer les capacités des jeunes à aspirer et à réaliser leurs aspirations avec une transition de la zone de développement proximal à la zone de développement aspiré, à savoir, la reconnaissance, les expositions, l'auto-croissance et la transférabilité. Nous avons recommandé d'autres études de recherche sur l'évaluation de l'efficacité de l'utilisation du cadre ED pour appliquer l'approche par les capacités au renforcement des capacités professionnelles des utilisateurs de services caractérisés par la diversité et la vulnérabilité dans différents contextes de services.

\section{Zusammenfassung}

\section{Verbesserung der Karrieremöglichkeiten von NEET-Jugendlichen in Hong-} kong: Ein erfahrungsorientierter Rahmen.

Inspiriert von Amartya Sen's Konzeptualisierung von Fähigkeiten untersuchte dieser Artikel, wie die Einführung eines erfahrungsorientierten (ED) Rahmens in den Fähigkeitsansatz dazu beitragen kann, die Bereitstellung eines Karriereunterstützungsdienstprojekts für Jugendliche im Alter von 15 bis 21 Jahren, die sich nicht in Ausbildung befinden, zu informieren, Beschäftigung oder Ausbildung (NEETJugendliche) mit Schwierigkeiten, ihre beruflichen Fähigkeiten zu entwickeln. Basierend auf einer thematischen Analyse von zehn individuellen Interviewtranskripten, die von fünf Berufspraktikern und fünf ehemaligen Nutzern gesammelt wurden, diskutierte die Studie vier ineinandergreifende Erfahrungsbereiche und erfahrungsgesteuerte Karriereinterventionen zur Verbesserung der Fähigkeiten von Jugendlichen, Ziele zu erreichen und Ziele mit einem Übergang von der Zone zu verwirklichen der proximalen Entwicklung zur Zone der angestrebten Entwicklung, nämlich Anerkennung, Exposition, Selbstwachstum und Übertragbarkeit. Wir empfahlen weitere Forschungsstudien zur Bewertung der Wirksamkeit der Verwendung des EDRahmens für die Anwendung des Fähigkeitsansatzes zur Stärkung der beruflichen Fähigkeiten von Dienstleistungsnutzern, die durch Vielfalt und Verwundbarkeit in verschiedenen Dienstleistungsumgebungen gekennzeichnet sind.

\section{Resumen}

\section{Mejora de las capacidades profesionales de los jóvenes NINI en Hong Kong: un marco basado en la experiencia.}

Inspirado en la conceptualización de capacidad de Amartya Sen, este artículo examinó cómo la introducción de un marco basado en la experiencia (ED) en el enfoque de capacidad ayuda a informar la entrega de un proyecto de servicio de apoyo profesional dirigido a jóvenes de 15 a 21 años que no están en la educación., empleo o formación (jóvenes NINI) con dificultades para desarrollar sus capacidades profesionales. Basado en un análisis temático de diez transcripciones de entrevistas individuales recopiladas de cinco profesionales de la carrera y cinco ex usuarios, el estudio analizó 
cuatro dominios entrelazados de experiencias e intervenciones profesionales basadas en la experiencia para mejorar las capacidades de los jóvenes para aspirar y realizar aspiraciones con una transición de la zona. de desarrollo próximo a la zona de desarrollo aspirado, a saber, reconocimiento, exposiciones, autocrecimiento y transferibilidad. Recomendamos más estudios de investigación sobre la evaluación de la efectividad del uso del marco ED para aplicar el enfoque de capacidad para fortalecer las capacidades profesionales de los usuarios del servicio caracterizados por la diversidad y la vulnerabilidad en diferentes entornos de servicio.

\section{Introduction}

An increasing population of youth not in education, employment or training (NEET) has become a global concern in developed economies. In Organisation for Economic Co-operation and Development (OECD) countries, $11.9 \%$ of youth population aged 15-24 were NEET in 2018 (World Bank, 2019). The corresponding figure in Hong Kong was 65,068 accounting for 8.9\% of those aged 15-24 (Office of Government Economist Financial Secretary's Office, 2018). Yet, against the backdrop of social unrest erupting in 2019 and the outbreak of COVID-19 pandemic since early 2020, Hong Kong is now confronting challenges in containing an increasing number of NEET youth and addressing the consequent socioeconomic problems caused by the loss of earnings and increased public finance.

The deprivation of a legitimate social status as a student, worker or trainee is unfavourable for enhancing the self-esteem of NEET youth, who are not able to equip themselves with an impressive resume of educational credentials and remarkable paid work experience (Su et al., 2020a). Research studies have shown that youth aged 24 or below with a longer spell of NEET status suffer from the long-term detriments of 'scarring effects' of unemployment, which will lead to enduring economic hardship and social exclusion in the long run (Edgell \& Beck, 2020; MojsoskaBlazevski et al., 2017). For those NEET youth with additional vulnerability such as prolonged self-seclusion experience or special education needs, they found it even more difficult to regain a legitimate social status for enhancing self-esteem and seeking social recognition (Su et al., 2020a, 2020b).

The provision of context-sensitive career support services is deemed important to support the career development of marginalized youth (Bimrose et al., 2015) through expanding the sources of experience and recognition (Honneth, 2003; Van den Brink \& Owen, 2007) in order to facilitate them to make sense of their being, doing and becoming (Giovanola, 2007). In view of the lack of experiences, skills and exposures of marginalized NEET youth, the application of an experience-driven framework characterized by the provision of resources, opportunities and networks through involving multiple stakeholders was to inform the design and delivery of career support services in community settings (Su \& Wong, 2020a; Wong \& Yip, 2019; Wong et al., 2021). Such a framework aimed to promote people's freedom to achieve the functioning and aspirations they value, exercise individual agency, explore resources and opportunities in various learning and work domains, and enhance their adaptability and capabilities in confronting challenges that 
individuals, especially those with vulnerability, have to face every day (Robertson, 2015; Savickas, 1997; Sgaramella \& Ferrari, 2019).

It is against this social and conceptual backdrop that a five-year-long career support service project (thereafter the project) funded by the Hong Kong Jockey Club Charities Trust, which was targeted to NEET youth and NEET youth-at-risk aged 15-21 was implemented by five district service teams all over Hong Kong since 2015. Each service team employed around eight social workers as career practitioners to deliver career guidance, counselling and interventions for youth clients on a one-on-one and group basis as appropriate. The project also established a research team housed in a university where the authors are/were affiliated to, which took up the responsibility to evaluate programme effectiveness and consolidate the service design and delivery experience for promoting knowledge transfer. Up to February 2020, the project had served 7200 NEETs. The average duration of service for each youth client was around nine months (Wong \& Yip, 2019; Wong et al., 2021).

\section{Towards a capability approach to career support services}

The capability approach developed by Amartya Sen emerged as a humane approach to promoting economic and welfare development (Sen, 1993, 2001, 2003, 2008). The concept of capabilities refers to what people will be able to do given that opportunities are available, which is distinguished from the concept of functionings understood as achieved abilities (Krishnakumar, 2007). Programmes informed by the capability approach call for attention to what young people really want for their own lives, what their interests dwell in and how they tend to define themselves with their evolving experiences (Edgell \& McQuaid, 2016; Hollywood et al., 2012). The capability approach challenges the existing normative framework overemphasizing the importance of educational and career credentials and offers space for discussing how policy making, service delivery and professional practice can expand both symbolic and tangible resources to recognize and realize the talents and aspirations of youth (Avis, 2014; Orton, 2011). Moreover, transition to paid work within a short period is not necessarily a positive antecedent leading to quality employment or life (Vero et al., 2012). The capability approach instead takes expanded and meaningful options defined by the beholders (Deneulin, 2011) and a critical examination of the diverse impact of career interventions (Fuertes et al., 2021; Joncas \& Pilote, 2021) being central to enhancing the life design and career capability development of service users (Pouyaud, 2016; Robertson, 2015; Robertson \& Picard, 2021).

Sen only outlined the capability approach in general terms without providing lists of capabilities or specifying how this approach can be used in various contexts (Robertson, 2015; Robertson \& Egdell, 2018; Zimmermann, 2006). Egdell and Robertson (2021) argued that a lack of sociological analysis of conversion factors discussed in Sen's capability approach is not favourable for informing the design of career interventions and turning resources into positive career-related outcomes. Hart and colleagues (Hart, 2016; Hart \& Brando, 2018; Hart et al., 2014) proposed two core capabilities, namely, the capability to aspire and the capability to realize aspirations as important components to operationalize the capability approach to 
working with children in school or educational settings. Both Edgell and Graham (2017) and Robertson (2018) highlighted the importance of taking unpaid work and interest-based activities as alternative meaningful options for enhancing the design and delivery of career support services targeted at marginalized youth. This implies that there is a need to acknowledge the experience of NEET youth involved in these activities largely unrecognized by mainstream society, expand their sources of exposure, experience and recognition, and enhance their life-design capability to develop a career pathway most preferred by themselves. Yet, empirical research needs to explore whether the capabilities to aspire and realize aspirations are also crucial for marginalized youth's career capability development in community settings and how the capability approach can inform the design and implementation of career support services for NEET youth with additional vulnerability in particular.

\section{Experience-driven framework for informing career capability development}

Central to the idea of school-to-work transition is youth's entry into employment, which has, however, underestimated the link between paid and unpaid work (Edgell $\&$ Granter, 2019). The development of the experience-driven framework is based on the expanded notion of work (ENOW) model (Wong, 2015), which unpacks the notion of work into six different categories of paid and unpaid work. Paid work is of two categories, namely, a) employment and entrepreneurship, and b) work trials, paid internship, and trial-run business. The world of unpaid work is of a wider spectrum, the first of which is vocational education and training, and other work exposure programmes. The next two are volunteering activities largely organized by NGOs, and provisioning undertaken in non-organizational contexts such as selfcare, family care and neighbourhood care. The last one is serious leisure theorized as an intensive and committed pursuit of a leisure-time activity (Stebbins, 2017) such as street dancing, online game playing, music busking, among many others. The ENOW model shows that both formal and informal economic activities (Watts, 2015) are the constituent and transferable elements of the holistic landscape of work and work experiences (Wong \& Yip, 2019).

Emphasizing both self-recognition and social recognition, Honneth's recognition model indicated that realizing an autonomous life is intersubjective rather than individualist in nature (Honneth, 1996, 2003, 2014). When NEET youth fail to achieve self-recognition and social recognition, it is difficult for them to initiate changes by taking autonomous actions. The journey of struggling for recognition (Honneth, 1996) will become an insurmountable one if sustainable support from different stakeholders such as parents, helping professionals, employers and mentors is not available. Against the sociocultural background that paid work is much highly valued over unpaid work in mainstream discourse, the ENOW model is operationalized by an experience-driven framework (Su \& Wong, 2020a) to inform the design, delivery and evaluation of career support services. This is particularly relevant to late-modern societies such as Hong Kong where academic achievements and paid work experiences have a strong cultural value attached to them, whereas 
unpaid work experiences, and hobbies, leisure and interests are often viewed as a distraction for making a smooth transition to further study or work. The experiencedriven framework emphasizes the importance of acknowledging the untold experiences of unpaid work undertaken by NEET youth clients and the strategic role of enriching and reviewing their participation in a wide spectrum of interest- and workbased activities as a solid ground for pursuing their career aspirations (Wong \& Yip, 2019). All this is helpful to facilitate youth clients to identify what they value for life, navigate a relevant career pathway, and thus enjoy freedom from merely following the conventional career roadmap leading to success. The experience-driven framework incorporates two crucial elements for practicing the capability approach to enhance the life-design capability of youth clients, namely, co-construction of a zone of aspired development and mobilizing support from more enabling others.

\section{Zone of aspired development (ZAD) and more enabling others (MEO)}

According to Vygotsky, social interaction is very important for enhancing the learning process of children and youth. With support from more knowledgeable others (MKO), young people will be able to develop new skills for problem solving in a faster manner than they work on their own. Vygotsky (1978, p. 86) proposed the concept of zone of proximal development (ZPD) as "the distance between the actual developmental level as determined by independent problem solving and the level of potential development as determined through problem-solving under adult guidance, or in collaboration with more capable peers". In the project, the term MKO refers to those older adults, mentors or peers who are more knowledgeable, capable and experienced than individual learners in a certain area of interest, trade or industry. When the learners become more competent along with growing experience, they can finish more tasks on their own without involving the MKO.

Moreover, the experience-driven framework emphasizes facilitating youth clients' transition from their ZPD to a zone of aspired development by involving the participation of more enabling others. The term zone of aspired development (ZAD) refers to the move of young people from the ZPD to another zone in which young people with aspirations are able to navigate their career pathway ahead in spite of anticipating confronting risks and uncertainties. In the ZAD with growing adventures and aspirations, young people are keen on building up aspirations and taking up future-informed actions to develop capabilities to realize their aspirations by proactively seeking and making good use of resources, opportunities and networks. The involvement of more enabling others (MEO) is helpful to facilitate youth clients to make a move from the ZPD to the ZAD. Unlike the counterparts of $\mathrm{MKO}$, more enabling others are not necessarily more knowledgeable than the youth clients in a certain area of interest or trade such as music or bakery. MEO are instead committed to facilitating youth to build up their aspirations, provide useful information for their informed career decision-making and/or bridge them up with more resources, opportunities and networks for pursuing their preferred career pathway (Su \& Wong, 2020a). As shown in Figure 1 below, career practitioners can provide the four domains of experience-driven career interventions, 


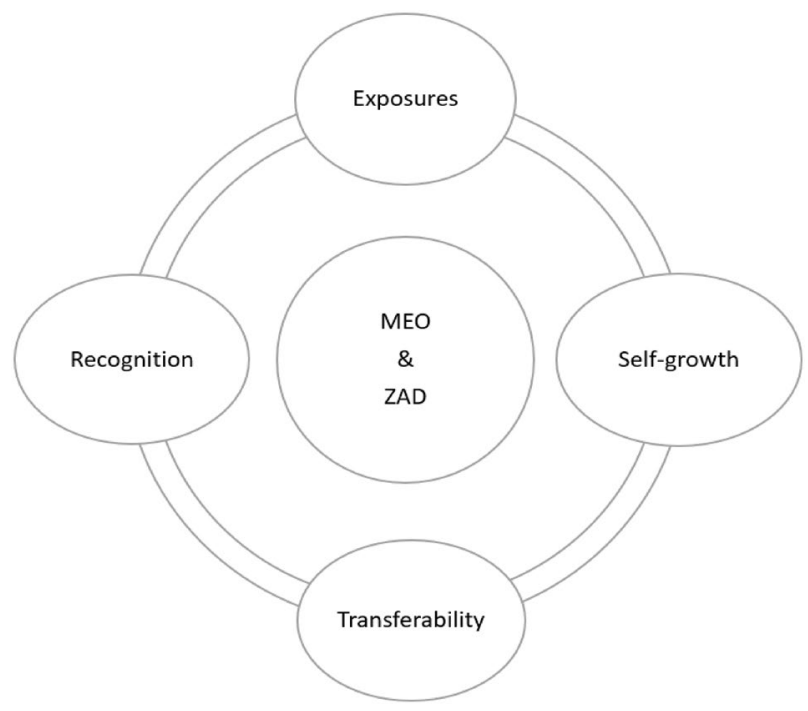

Figure 1 The experience-driven framework for enhancing the career capabilities of NEET youth

namely, recognition, exposures, self-growth and transferability for facilitating youth clients to make a move from the ZPD to their preferred ZAD and leveraging the involvement of more enabling others as resourceful persons or mentors.

\section{Aims of the study and research questions}

The study aimed to examine how the experience-driven framework worked to apply the capability approach in career support services for NEET youth with different types of vulnerability implemented in the community settings of Hong Kong. The following three interrelated research questions were answered by conducting qualitative individual interviews with five ex-users as youth participants and five social workers of the project as practitioner participants. First, how did NEET youth with different types of vulnerability experience their own career capability development in relation to the capabilities to aspire and realize aspirations? Second, how were the four domains of career interventions informed by the experience-driven framework conducive to enhancing the career capability development of youth with different types of vulnerability? Finally, how did practitioners support the career capability development of NEET youth with different types of vulnerability by facilitating them to transition from the zone of proximal development to the zone of aspired development and involving the participation of more knowledgeable others and more enabling others? 


\section{Method}

Semi-structured individual interviews were used to examine the user journey of exusers of the project. User journey refers to the processes and experiences of service users as seen from the user perspective (Liu, 2019; Su \& Wong, 2020b), which is characterized by a dynamic and interactive process positioned in between a departure point and an end point of the entire course of service delivery.

\section{Participants}

To choose typical yet heterogeneous cases of the project, this study purposively invited 29 ex-users, who were all NEET youth with specific additional vulnerability/vulnerabilities, to join a semi-structured individual interview. The breakdown of youth groups as participants are as follows: four ethnic minority youth, six young mothers, seven youth with prolonged self-seclusion experience, eight youth with special education needs, and four with multiple vulnerabilities who are youth with SEN and prolonged self-seclusion experience. Among the 29 ex-users, five youth participants were randomly sampled from each of the aforementioned ex-user groups for the study. A total number of 12 practitioner participants with relevant experience of working with these 29 ex-users were invited for an individual interview, who had all been equipped with $43 \mathrm{~h}$ of professional training on career interventions offered by the community-based team of the project chaired by the corresponding author. One practitioner participant was randomly sampled from each of the five different groups of career practitioners, and thus five practitioner participants were identified for the study.

Table 1 presents the sociodemographic information of the youth participants, their presenting vulnerability/vulnerabilities when they started joining the project, their duration as NEET, the length of their user journey, the major interventions they had been through and the outcomes of interventions. Table 2 presents the information of the practitioner participants, including their gender and the type of NEET youth. To assure personal privacy and confidentiality, gender-specific pseudonyms are used.

\section{Interviews}

The interviewers used a semi-structured interview guideline to facilitate each of the youth participants to talk about his/her relevant experience in the four following areas. That is i) needs and difficulties confronted before starting the user journey, ii) critical incidents and significant relationships encountered and self-perceived changes during and after the user journey, iii) current status and identity, and iv) finally aspirations for career and life development.

The interviewers of the research team asked the practitioner participants openended questions in the following areas. First, what were the career hurdles encountered by NEET youth with vulnerability? Second, how were the intervention 


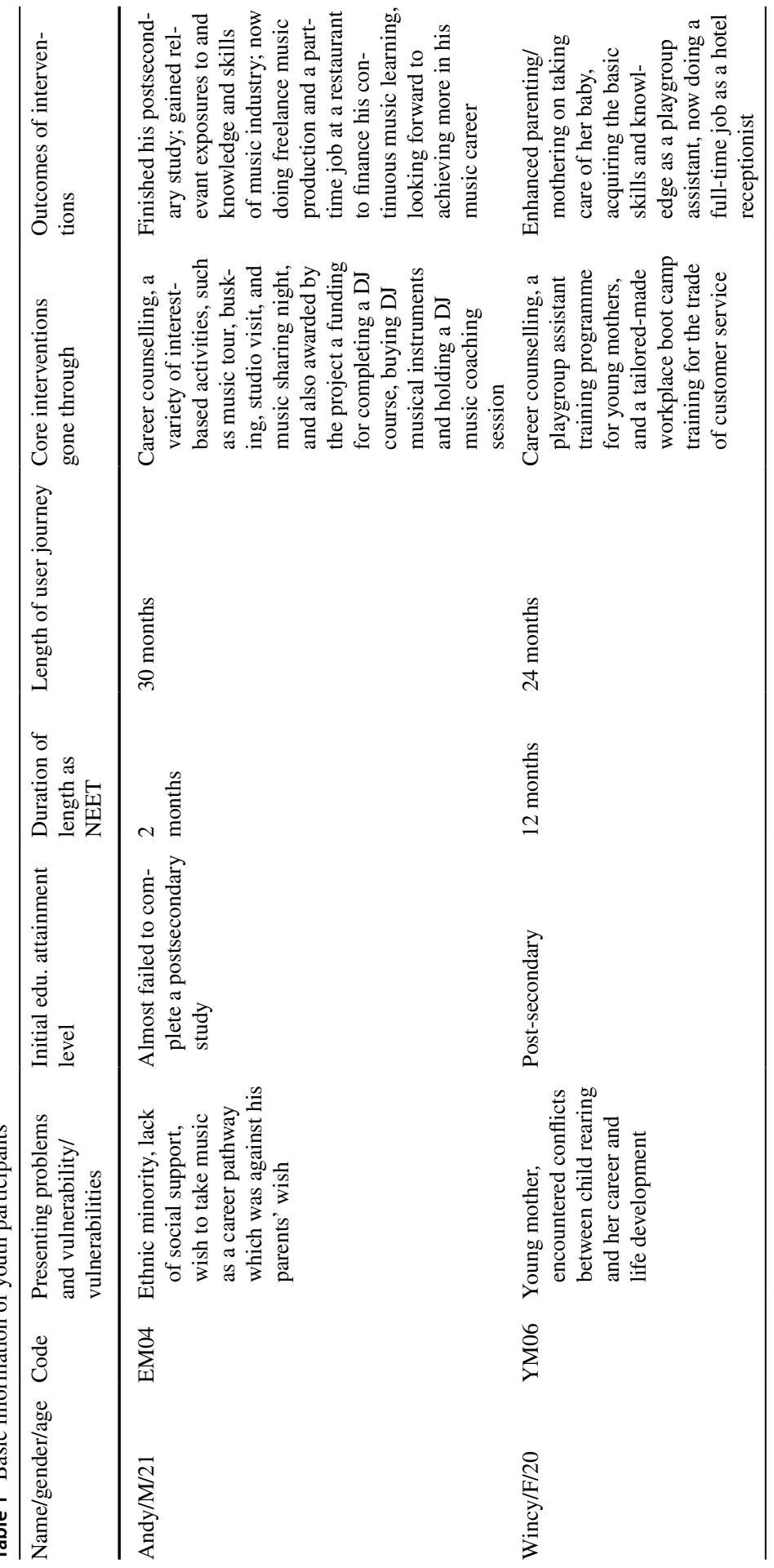




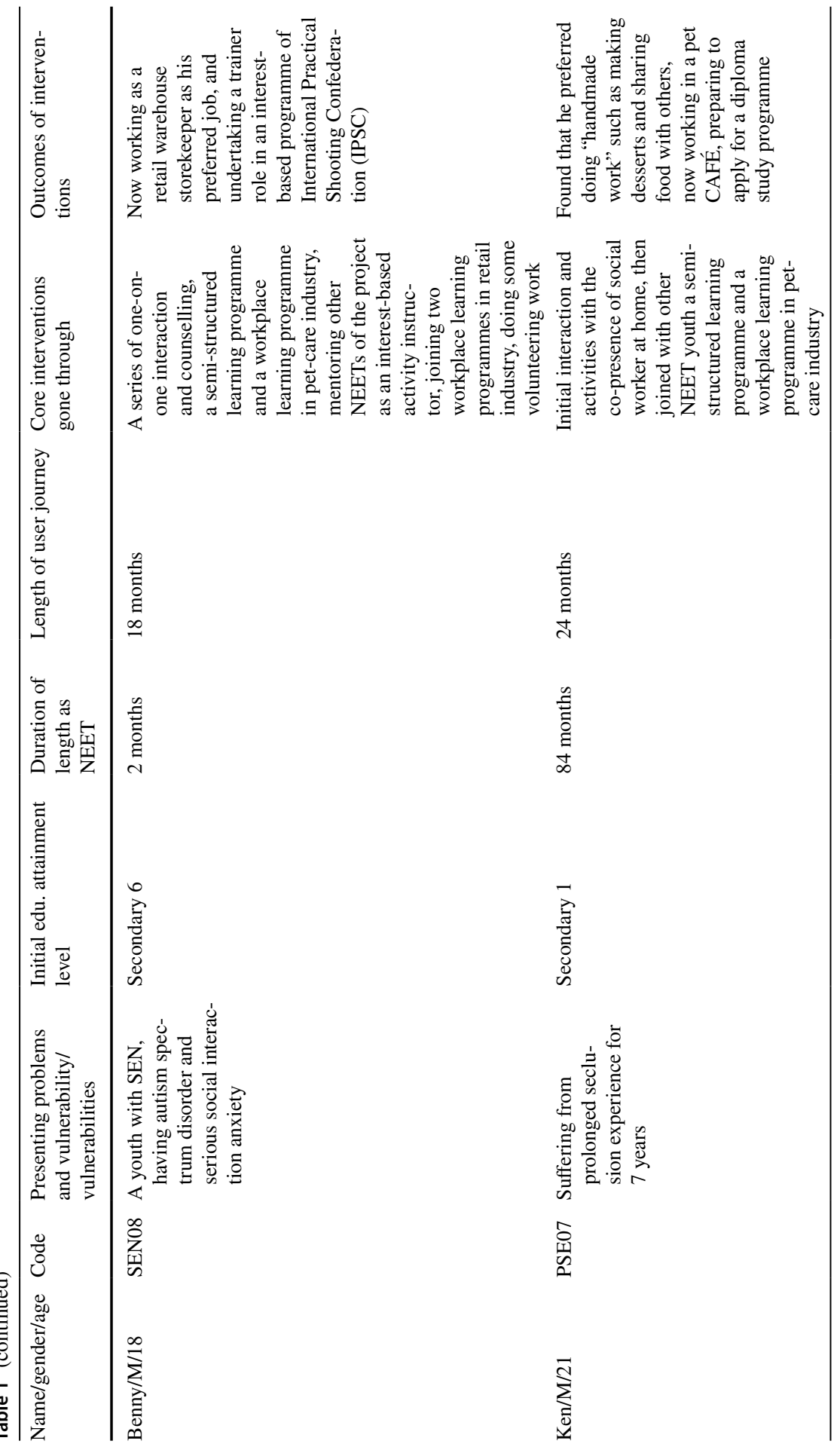




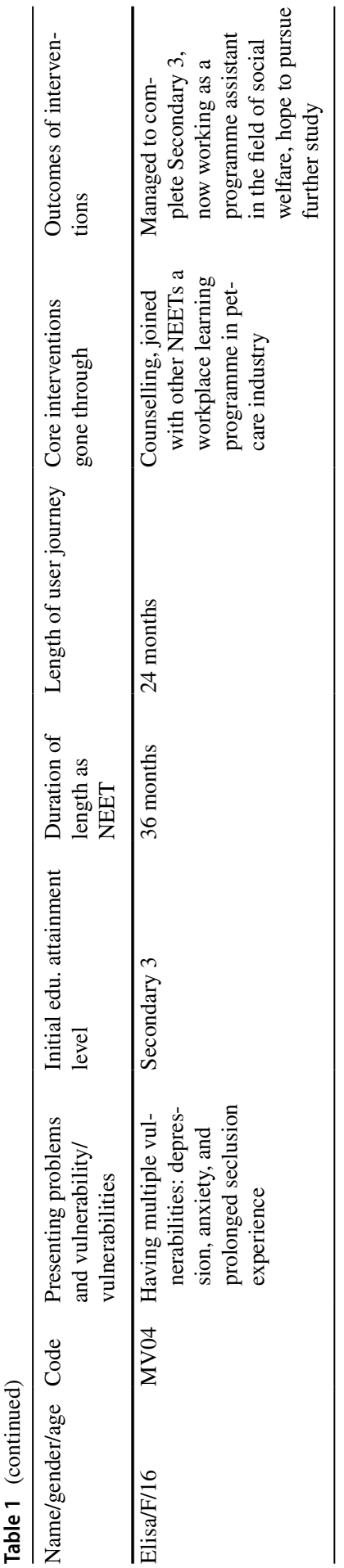


Table 2 Basic information of practitioner participants

\begin{tabular}{lll}
\hline Name/gender & Code & $\begin{array}{l}\text { With at least one year of experience of } \\
\text { working with a specific type of NEET } \\
\text { youth }\end{array}$ \\
\hline Sam/M & SW_EM01 & Ethnic minority youth \\
Lisa/F & SW_YM01 & Young mothers \\
Cathy/F & SW_SEN05 & Youth with SEN \\
Peter/M & SW_PSE03 & Youth with prolonged seclusion experience \\
Betty/F & SW_MV02 & Youth with multiple vulnerabilities
\end{tabular}

programmes designed to be experience-driven and tailor-made to the specific user group? Third, how can the ENOW model and the project's use of resources, opportunities and networks support the development of career capabilities of youth? Fourth, what were the roles played by different stakeholders such as career practitioners, employers and mentors in the project? Fifth, how did the interventions support showing recognition to youth and acknowledging youth agency in career support services? Finally, how did you leverage on interest- and work-based activities for working with youth with vulnerability?

Except one interview with an ethnic minority youth conducted in English, all the other interviews with youth and practitioner participants were conducted in Cantonese, the mother tongue of the participants. All interviews lasted for about $1.5 \mathrm{~h}$ The youth participants were encouraged to share and evaluate their personal experiences within and beyond the user journey. The practitioner participants were facilitated to review their working experiences with a specific user group and how they had adopted the experience-driven framework to enhance the career capabilities of NEET youth in community settings. This study adopted a thematic analysis approach to examining all the interview transcripts, which is to be detailed below.

\section{Procedures and ethics}

Prior to the study, the corresponding author obtained ethical approval from the research ethics committee of the university where he is affiliated with. Six interviewers including the first author recruited by the research team of the project conducted an interview with each of the participants on a one-on-one basis. After explaining the purpose and scope of the study, a signed informed consent was collected from each of the participants prior to the start of the interview. An audio recorder was used to record the interviewing process. All data collected were treated confidential and accessible to the research team only.

\section{Data analysis}

All recordings were transcribed into Chinese by undergraduate student helpers, which were counter-checked by the research team. To better identify nuances in the language and represent the participants' lived experiences and perspectives, the authors read and 
reviewed all transcripts in Chinese in the first place. They then analysed the contents of transcripts and identified the meaning units and themes embedded within the narratives. Next, common or related meanings were categorized together to constitute an initial theme, which is a 'recurrent pattern of human intention' and make up 'the level of story concerned with what the characters in the narrative want and how they pursue their objective over time' (McAdams, 1993, p. 67). Related themes were then connected and compared. The structure of narratives was also examined (Riessman, 2008). In this study, plot development was identified by considering how the participants selected, connected and sequenced separate episodes of experience within and beyond the user journey (Su \& Wong, 2020b). Emergent themes and their potential connections were continuously reviewed in preparation for writing up the finalized themes. Finally, to support the discussion to follow, representative verbatim quotes were identified, translated into English and reviewed for use accordingly.

\section{Rigour of the study}

To assure the rigour of the study, the following actions were taken. First, before conducting the semi-structured individual interviews, all interviewers had joined a 6-h training workshop provided by the research team of the project to learn about the interview guideline, the theoretical framework of the project, and the interventions provided to ex-users and delivered by career practitioners. Second, every participant received a thank-you note after the interview specifying the identity code of his/her interviewer and the office telephone number of the corresponding author for reporting any personal concerns related to the interview process as necessary. Third, as mentioned before, all the transcripts in Chinese were counter-checked by the research team before further processing. Finally, regarding the data analysis process, the first and corresponding authors analysed the ten interview transcripts separately before holding a meeting to discuss the codes, themes and subthemes derived from the data for reaching a consensus.

\section{Results}

Based on an inductive-deductive approach to conducting a thorough thematic analysis of the qualitative data, the study identified themes and subthemes accordingly. Overall speaking, two crucial career capabilities needed by NEET youth with additional vulnerability/vulnerabilities, four interlocking domains of experiences and experiencedriven career interventions, and two important levers used throughout the process for enhancing the career capabilities and life design of the clients were examined and summarized in Table 3. 


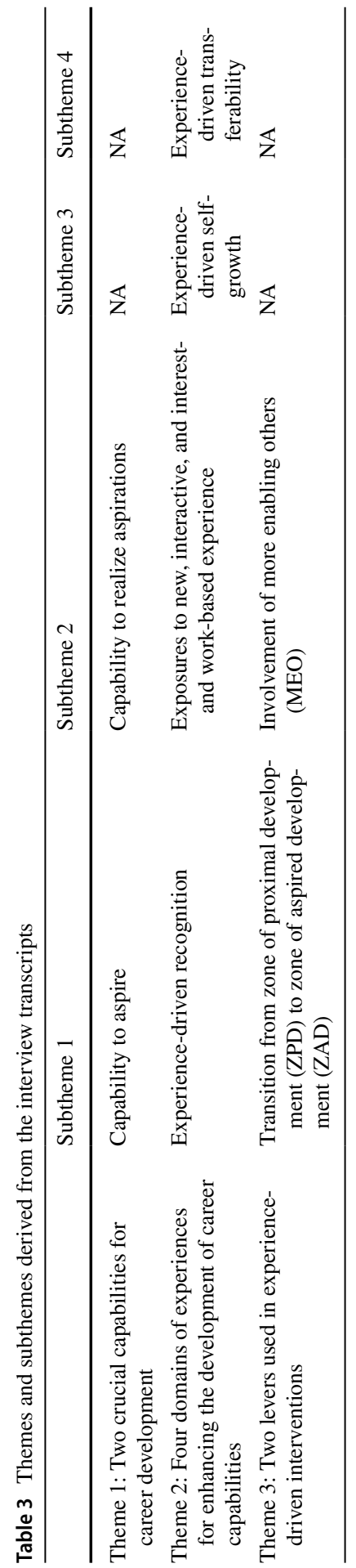




\section{Theme 1: two crucial capabilities for career development}

In this study, the capability to aspire and the capability to realize aspirations were deemed crucial for NEET youth with additional vulnerability/vulnerabilities in relation to enhancing their career capability and life design as follows.

\section{Subtheme 1: capability to aspire}

Our youth participants were suffering from a low capability to aspire resulted from their lack of experiences, exposures, abilities, resources, opportunities and networks, and their prior traumatic experience. For example, after dropping out from school, Elisa self-secluded herself at home without any face-to-face interaction with anybody else other than her parents. Elisa was not in a state to aspire for anything before joining the project.

My energy level nearly went down to zero even to the point of having no energy to go to die. I cannot handle the stress imposed by schooling. But I never thought about seeking for any other alternative pathways other than pursuing mainstream education, until my situation became extremely bad. (Elisa, MV04, aged 16)

Ken had self-secluded himself at home without making any social contact at all for a long period of seven years. He even did not have his own mobile phone. Many social workers tried to reach out to Ken, but unfortunately failed to establish any working relationship with him. Benny, describing himself as an "invisible" student in his school life, was having special education need (SEN) with autism spectrum disorder (ASD) and serious social interaction anxiety. His family support was weak as he only lived with his mother (who just occasionally showed up at home), auntie and grandmother.

For clients like Elisa, Ken and Benny, their prior 'failure' experiences at school disabled and disempowered them from developing any aspirations particularly in view that they had no information about alternative career pathways except pursuing mainstream education. Through experience-driven interventions, Benny developed his aspiration to work in an environment with low level of social interaction, and finally resolved to work in a retail company as a warehouse storekeeper. Moreover, his serious interest in practical shooting developed through his participation in a series of interest-based activities offered by the project has enabled him to become a trainer and encouraged him to become a professional player in this sport by committing himself to further training. Andy, an ethnic minority youth fond of music gained no support from his parents as the latter just thought that music has no value for making a living. Over the course of user journey, Andy finally managed to reconfirm his commitment in music with his parents' support.

Ethnic minorities gained very little social support. There can be a great discrepancy between parents' expectations and self-expectation of the youth clients. For example, the fathers may urge their male children to get married as 
soon as possible and give birth to a kid and then pursue a job like their fathers did. But what the youth clients really wanted for their own life? They were not sure and had no way to confirm their own thoughts. (Sam, SW_EM01)

\section{Subtheme 2: capability to realize aspirations}

As shown in the study, the NEET youth clients with additional vulnerability/vulnerabilities also suffered from the lack of capability to realize their aspirations due to their limited abilities and skills, low educational attainment, and lack of paid work experience and social support. In addition to being incapable of pursuing academic achievement, they also found them incapable of pursuing what they had passion for, as they enjoyed no access to relevant resources, opportunities, and networks before joining the project as service users.

After completing a foundation diploma, Wincy became pregnant. She faced common hurdles like many other young mothers including (1) insufficient knowledge on taking care of baby, (2) taking care of new-born baby alone without much support, (3) financial burden and (4) limited peer support due to change of social circle. The provision of an enabling environment in terms of free baby-sitting service, playgroup assistant training and workplace training boot camp could help Wincy voice out emotions and needs in relation to child rearing and seeking means to overcome hurdles confronted in her career and life journey.

Working as an assistant in a pet hotel as part of a semi-structured learning programme was taken as an opportunity for Elisa to practice and improve her social skills when interacting with others including the customers in the internship environment. Although she found this kind of pet-care job not suitable to her, Elisa resolved to resume and finally complete her Secondary 3 study. Now she is working as a programme assistant in the field of social service, which is good for her to explore further her career and life development ahead.

Ken joined a semi-structured learning programme and a workplace learning programme in pet-care industry and connected with different people and groups through the programmes about caring for pets and animals, and learned how to use public transport and communication apps for making a reconnection with society. Upon completing a practicum in a pet hotel and a desserts shop, Ken found that he preferred doing "handmade work" such as making desserts and sharing food with others. With the support of the project, Ken is now working in a pet CAFÉ, and is preparing to apply for studying a diploma programme equivalent to a Secondary 6 qualification. With counselling service and emotional support from his career practitioner, Andy successfully completed his last-semester study of hotel management, and he is on his way to pursue his music career. The little but evident success achieved during the user journey paved way for realizing youth clients' preferred career pathways, as echoed by Peter, a practitioner participant, as follows:

When the youth clients finished their job placement in the workplace programme... we had multiple pathway choices available for them. We talked with them to confirm whether they really want to pursue more in this industry and we assessed whether they have picked up some basic skills and knowledge 
to take a relevant job. For those who were ready to work, we helped them to seek a formal job. For those who were interested but not skillful enough, we would suggest them to take more training or courses as the next step. (Peter, SW_SW03)

\section{Theme 2: four domains of experience for enhancing the development of career capabilities}

The career interventions informed by the experience-driven framework enhanced the youth clients' capability to aspire and the capability to realize aspirations through going through four interlocking domains of experiences, namely, recognition, exposures, self-growth and transferability.

\section{Subtheme 1: experience-driven recognition}

Betty (SW_MV02), the practitioner participant with experience of supporting NEET youth with multiple vulnerabilities, sadly pointed out that "even a salesperson is required to have Secondary 6 educational credential, which is not sensible" but she understood that there is a long way to go to advocate any ecosystem changes for constructing a more youth-friendly and enabling society. Criticizing the mainstream discourses, practitioners of the project opted to acknowledge the evolving functionings of youth clients based on their unpaid work experience in particular.

Our interventions are informed by the ENOW model. Through acknowledging their unpaid work experience, we hope that they will be aware of their long-term contributions to their families and to society. We also support them to thicken their values, attitudes, skills and knowledge developed from these experiences. (Lisa, SW_YM01).

Apart from acknowledging prior experiences of youth clients, practitioners also provided opportunities for youth to achieve social recognition from different stakeholders by participation in various exposure and mentoring activities. For example, youth clients were able to get feedback regarding their performance in workplace learning from frontline mentors, supervisors, or even the boss. Cathy (SW_SEN05), a practitioner participant with experience of working with NEET youth with SEN revealed that recognition from the supervisors in the practicum could motivate youth participants to make improvement. A young mother taking up a caregiver role acknowledged receiving recognition from her peer participants as follows:

Other participants thanked me for taking good care of their children when they were enjoying the activities. I didn't expect that I can handle several kids at one time. The social worker said some mothers yelled at the children but I was so peaceful and so patient. One participant said her child was very naughty to handle. They all said I am a patient person. I felt good to hear the compliments. (Wincy, YM06, aged 20) 


\section{Subtheme 2: exposures to new, interactive, and interest- and work-based experience}

As the youth clients were lack of exposures relevant to their interest development, the project provided them new, interactive, and interest- and work-based experience with the involvement of peers, mentors, career practitioners or other stakeholders. The following quote could illustrate how the provision of exposures functioned to confirm Andy's career pursuit in music.

The project brings in different guests...they bring in different musicians or artists for the sharing sessions. They broaden my horizon, make me know more about music, open up my mind on viewing alternative pathways to approach my goals. (Andy, EM04, aged 21).

As Benny was afraid of social interaction with others, he was encouraged to attend a semi-structured learning programme with a practicum in pet-care industry. After this workplace learning experience, he participated in a volunteering work project called "wheelchair escort service", which was followed by two other workplace learning programmes including taking the role as a shop assistant and as a warehouse storekeeper, respectively.

\section{Subtheme 3: experience-driven self-growth}

The third domain went through by ex-users for enhancing their career capability development is experience-driven self-growth which was manifested in terms of evolving self-understanding, abilities, confidence, character, connections and caring for others. Career practitioners used some tools to work with youth such as card-sorts and an all-rounded functional resume designed to archive their values, attitudes, skills and knowledge in order to review and thicken their expanded work experience and perceived self-growth and thus enhance their self-understanding (Su \& Wong, 2020b).

I think it is an exploratory and confirmatory process. I spent a lot of time to help my clients review their prior experience to enhance their self-understanding. When I was not sure what they can do, I need to offer them more exposures and then we can review and reconfirm along the way. I wanted to make sure if some of them cannot handle jobs that require human contact. (Betty, SW_MV04)

Elisa participated in different activities provided by the project, and mentioned that the workplace learning programme in pet-care industry made her grow a lot and reconnect with the community. Although Elisa did not find pet-care industry as her career preference, she learned how to make an informed choice for her own career and life development.

Now I am more open-minded. I used to assume that work is only for money and for living. But now, I understand that career is about life. Life is more than 
work, but also about interest. Through going through all those expanded work experiences, I am able to figure out what I really like, what I want to develop for my career, rather than simply for getting a job. (Elisa, MV04, aged 16)

\section{Subtheme 4: experience-driven transferability}

The last but not the least domain of career capability development experienced by the youth clients is experience-driven transferability, which emphasizes supporting them to transfer what they have acquired in one domain to another. For example, after going through the user journey, Elisa is able to transfer her values and attitudes of caring for others to her current position as a social service programme assistant. Although Benny has social interaction anxiety, his passionate participation in practical shooting had enabled him to work as a trainer for other youth clients and consequently his communication skill was further improved, which can be transferred to his current job as a part-time warehouse storekeeper with regard to cementing better collegial relationship in the workplace setting.

I was invited to introduce knowledge and skills of practical shooting to other youth clients. I didn't expect that I can speak in such a fluent way. I was not shy at all. I think I have improved. I can handle some non-demanding occasions. My current job is not demanding. I only need to talk to a few colleagues and I don't need to accommodate customers directly. I can do it. (Benny, SEN08, aged 18)

As to Wincy, the attitude of patience and its underlying value of caring for others shown and developed in baby-sitting and playgroup assistant training programme were transferable to the customer service as a hotel receptionist.

I have witnessed my own changes in the programme. I can take good care of the babies. I tried the post of playgroup assistant and I did handle it well. I also tried to search for a paid job. It is my growth in the playgroup learning program that motivated me to find a paid job. (Wincy, YM06, aged 20)

\section{Theme 3. two levers used in experience-driven career interventions}

The project enhanced the career capabilities of youth participants by using two levers: co-construction of a zone of aspired development and mobilizing support from more enabling others.

\section{Subtheme 1: transition from zone of proximal development (ZPD) to zone of aspired development (ZAD)}

In the project, career practitioners started engaging youth in the zone of proximal development and supporting them to transition into the zone of aspired development. For example, for NEET youth with prolonged self-seclusion experience 
(YPSE) such as Ken, the home environment was the last comfort zone to show them recognition by acknowledging the knowledge and skills embedded in their daily routines and interest-based activities (Su et al., 2020a, 2020b). The next step was for the career practitioners to work with YPSE into the neighbourhood community or service centre as an expanded comfort zone on a one-on-one basis. YPSE were then free to choose to join in a wide spectrum of interest activities, volunteering and workplace learning with others from which they can develop transferable values, attitudes, skills and knowledge to other domains of life such as education, employment or training (Wong, 2015; Wong \& Yip, 2019).

Ken was afraid of being looked down upon by others because of obesity which resulted from unhealthy diet and lack of exercise. However, the career practitioner from the project did not judge Ken at all. Instead, seeing from the capability lens, she was able to recognize Ken's desire to make simple desserts. Then, she took a step further to bring alongside the right kind of tools for enabling Ken to make desserts on his own at home. The ZPD constructed at home could help overcome Ken's inaction to venture into the community and his anxiety to interact with others.

Before I joined the project, my heart was haunted by the threat that everyone was discriminating against me... just feared that if everyone of them was thinking that I was too fat? Over the last five years, I actually had not talked to any other people at all. (Ken, SW07, aged 21)

\section{Subtheme 2: involvement of more enabling others (MEO)}

In the project, the role of more enabling others (MEO) was undertaken by career practitioners, workplace supervisors and mentors in interest-based activities. As MEO of youth clients, career practitioners supported the latter to acknowledge, thicken and reviewed their developed abilities and bridge up the youth clients with accessible resources, opportunities and networks to achieve what they have passions for. As summarized by Cathy, a practitioner participant below, Benny's MEO were those warehouse owners and frontline managers facilitating him to explore what he wanted to pursue further.

Benny has joined a number of workplace learning programmes before he finally settled down in a paid work...Our business partners not only shared with him about knowledge and skills of handling job tasks, but also shared work experience with him and offered him opportunities to try different pathways. (Cathy, SW_SEN05)

\section{Discussion}

This is the first study to examine how the experience-driven framework functions to enhance the career capability of NEET youth with additional vulnerability/vulnerabilities and make the life design perspective more conducive to working with marginalized youth by using empirical data drawn from a career support service 
delivered in community settings. The results of the study contributed to the existing literature by answering three aforementioned research questions.

First of all this study echoed the recent literature (Joncas \& Pilote, 2021; Robertson, 2015, 2018; Robertson \& Picard, 2021) for supporting an emerging trend to apply the capability approach to enhance the career development of NEET youth. Acknowledging that NEET youth is a heterogeneous group with or without additional vulnerabilities, Su et al., (2020a, b) revealed that they had one thing in common, i.e. lack of both self- and social recognition following the imposition of a stigmatizing NEET label on themselves and the consequent under-recognition and misrecognition of their prior and current interest and unpaid work experiences. This study revealed that NEET youth with additional single or multiple vulnerabilities might fail to define a roadmap for their career and development or fall into the state of helplessness and hopelessness. There is no dispute to the emphasis of using lifedesign dialogue and conversations to deconstruct limiting narratives and beliefs held by the clients, and co-constructing new narratives for formulating subsequent action plans for enhancing reflection and realizing aspirations (Guichard, 2018; Savickas, 2012). Yet, the capability approach also takes the provision of an enabling environment being central to supporting the capability development of marginalized NEET youth with additional vulnerability/vulnerabilities particularly in view of their limited sources of recognition. The findings of the study suggested that the stigmatizing label of NEET and the absence of a promising resume should not function as barriers for facilitating youth clients to articulate their untold and suppressed stories of unique outcomes that could inform the replotting of empowering narratives. Using the experience-driven framework for showing acknowledgement and recognition of prior clientele interest and experiences is different from the problematic story plots constructed and pursued along the line of victim blaming (Blustein et al., 2018). Following the experience-driven framework informed by the capability approach, career practitioners are to support NEET youth with or without vulnerabilities to construct, deconstruct, reconstruct and co-construct their life stories and narratives (Savickas, 2015) with the provision of resources, opportunities and networks available from the engagement of multiple stakeholders.

Second, the study revealed that the capability to aspire and the capability to realize aspirations proposed by Hart and colleagues (Hart, 2016; Hart \& Brando, 2018; Hart et al., 2014) were crucial for the capability development of NEET youth with additional vulnerability/vulnerabilities in community settings. As shown from the above analysis, these youth participants failed to develop two crucial career capabilities that can enable them to live and realize a life they value, namely, capability to aspire and capability to realize aspiration. Moreover, the findings of the study showed that the capability to aspire is not a one-off task but an ongoing one characterized by dynamics and complexity in search of both self- and social recognition along the user journey and beyond. In this connection, the application of experiencedriven framework is strategic in translating the abstract and unspecified framework of Sen's capability approach to designing and implementing career support services targeted to youth with single or multiple vulnerabilities.

Another important finding of the study is the unpacking of the four interlocking domains of experiences understood as a process for cultivating the two crucial 
yet-to-be developed capabilities of NEET youth with different types of vulnerability, namely, recognition, exposures, self-growth and transferability. Informed by the insights from Edgell and Graham (2017) and Robertson (2018), this is the first ever study using an experience-driven framework with four domains of experiences, and examining how the framework functioned to enhance the career capabilities of those NEET youth pushed to the margin of society. Experience-driven recognition serves not only as a starting point for the acknowledgement of prior and current experiences but also as a key component across all three other domains of experiences leading to experience-driven exposures, self-growth and transferability. Enhanced self- and social recognition can motivate youth clients to welcome new, interactive exposures, enjoy self-growth and realize the transfer of values, attitudes, skills and knowledge from one sphere to another as appropriate. Exposures to new, interactive and interest- or work-based experiences may lead to self-growth and vice versa. For example, all along the user journey, Andy developed not only a coherent narrative of mindset, heartset and skillset (e.g. Heto \& Indangasi, 2020) in music performance and music production, but also the readiness to build up a stronger capability to facilitate peers and new comers to ignite their serious interest in music as his career. Except young mothers such as Wincy who could manage to immediately apply what she had learned from the playgroup assistant programme to her daily parenting and provisioning tasks within the domestic context, transferability was usually materialized upon approaching the end of user journey. With support from career practitioners, youth participants were able to review what they had learned from the project, and applied or transferred what they had learned beyond their user journey as appropriate.

Finally, another important finding of the study revealed two experience-driven levers used across four interlocking domains of experiences throughout the entire user journey of youth participants, namely, more enabling others (MEO) and zone of aspired development (ZAD). Conceptually, the study distinguished the differences between MKO and MEO, and between ZPD and ZAD, which could help add values to Vygotsky's sociocultural learning theory for informing experience-driven career interventions for enhancing the capabilities of marginalized youth in pursuing their career ahead within a context-sensitive enabling environment characterized by the proactive involvement of multiple stakeholders. Acknowledging prior and current interest and unpaid work experiences of youth in their zone of proximal development can help enhance trust building for paving the way for transitioning to the zone of aspired development and expanding the sources of experience favourable for expanding the base and sources of recognition, self-growth and transferability throughout and beyond the user journey.

\section{Limitations}

Nevertheless, this study has its own limitations. This study only purposively sampled five types of NEET youth participants with additional single or multiple vulnerabilities and five practitioner participants with relevant experience of working with any specific marginalized youth group. We therefore need to be cautious about 
drawing any definite conclusions regarding the transferability of research findings to other different types of vulnerability such as physical disability, mental health challenges and visual disability. As the duration spent by youth as NEET is an important indicator to address the needs of NEET youth (Su et al., 2020a), future studies are needed to investigate how shorter duration and longer duration spent by youth as NEET with or without additional vulnerabilities influence the application of the experience-driven framework. Finally, the experience-driven framework was only adopted by the project in working with NEET youth in community settings, future studies are in need to study the extent to which this experience-driven framework is applicable to school settings or to other age groups such as younger or older adults with regard to strengthening their career capabilities and life design.

\section{Implications for research and practice}

The study sheds light on conducting research studies around the dual responsibilities of career practitioners in terms of developing tailor-made interventions to meet the needs and aspirations of youth and enhancing the capacity and capability of multiple stakeholders to work with marginalized NEET youth with additional single or multiple vulnerabilities. The project offered $43 \mathrm{~h}$ of professional training package on career interventions to all social workers including introducing three waves of career theories and experience-driven career interventions and tools for working with youth clients informed by the expanded notion of work model, capability approach, life design theory and practice, and recognition theory. Moreover, the training package also addressed the strategies and tactics to work with multiple stakeholders including employers and mentors. Further research studies are recommended for evaluating this training package informed by the experience-driven framework for working with youth in school and community settings, and other clientele groups who are at the margin of society in particular.

\section{Conclusions}

The study revealed that using the experience-driven framework informed by the capability approach, career practitioners are able to empower NEET youth with additional single or multiple vulnerabilities to enjoy the freedom to aspire and realize their career aspirations with new narratives and evolving career aspirations. To provide marginalized youth an enabling environment favourable for informing life-design dialogue, guidance and interventions, career practitioners have to equip themselves with the capability perspective and work with multiple stakeholders including employers, mentors and coaches with enhanced capacity for showing youth acknowledgement and recognition. Working with marginalized NEET youth in their zone of proximal development and facilitating them to transition to the zone of aspired development across four interlocking domains of experiences is anything but easy. Career practitioners are to work with youth in vulnerability contexts by involving the participation of multiple partners in 
diverse settings, who are willing to and capable of taking up the challenging positions as MKO and MEO if individual agency of youth and social justice for youth are to be achieved in a sustainable manner.

Acknowledgements The authors would like to give special thanks to all the participants for sharing their experiences and opinion and the funding support from the Hong Kong Jockey Club Charities Trust.

Author contributions The authors contributed equally to the article.

Funding We acknowledge the Hong Kong Jockey Club Charities Trust for the funding support for this study [HKBU/HKJCCT/14-15/012].

Data availability The corresponding author takes responsibility for the integrity of the data and the accuracy of the data analysis.

\section{Declarations}

Conflict of interest The authors declare that they have no financial or personal relationships that may have inappropriately influenced them in writing this article.

Ethical approval All procedures performed in studies involving human participants were in accordance with the ethical standards of the Research Ethics Committee of Hong Kong Baptist University and with the 1964 Helsinki declaration and its later amendments or comparable ethical standards. This article does not contain any studies with animals performed by any of the authors.

Informed consent Informed consent was obtained from all individual participants included in the study.

\section{References}

Avis, J. (2014). Comfort radicalism and NEETs: A conservative praxis. International Studies in Sociology of Education, 24(3), 272-289. https://doi.org/10.1080/09620214.2014.943030

Bimrose, J., Mulvey, R., \& Brown, A. (2015). Low qualified and low skilled: The need for context sensitive careers support. British Journal of Guidance \& Counselling, 44(2), 145-157. https:// doi.org/10.1080/03069885.2016.1145190

Blustein, D. L., Duffy, R. D., Kenny, M. E., Gutowski, E., \& Diamonti, A. J. (2018). The psychology of working theory: A transformative perspective for a challenging era. In N. Arthur \& M. McMahon (Eds.), Contemporary theories of career development: International perspectives (pp. 153-165). Routledge.

Deneulin, S. (2011). Development and the limits of Amartya Sen's “The Idea of Justice." Third World Quarterly, 32(4), 787-797.

Edgell, V., \& Graham, H. (2017). A capability approach to unemployed young people's voice and agency in the development and implementation of employment activation policies. Social Policy \& Administration, 51(7), 1191-1209. https://doi.org/10.1111/spol.12262

Edgell, S., \& Granter, E. (2019). The sociology of work: Continuity and change in paid and unpaid work. London: SAGE.

Edgell, V., \& McQuaid, R. (2016). Supporting disadvantaged young people into work: Insights from the capability approach. Social Policy \& Administration, 50(1), 1-18. https://doi.org/10.1111/ spol. 12108

Egdell, V., \& Beck, V. (2020). A capability approach to understand the scarring effects of unemployment and job insecurity: Developing the research agenda. Work, Employment and Society, 34(5), 937-948. https://doi.org/10.1177/0950017020909042 
Egdell, V., \& Robertson, P. J. (2021). A critique of the Capability Approach's potential for application to career guidance. International Journal for Educational and Vocational Guidance, 21(2), 447-463. https://doi.org/10.1007/s10775-020-09445-0

Fuertes, V., McQuaid, R., \& Robertson, P. J. (2021). Career-first: An approach to sustainable labour market integration. International Journal for Educational and Vocational Guidance, 21(2), 429-446. https://doi.org/10.1007/s10775-020-09451-2

Giovanola, B. (2007). Personhood and human richness: Good and well-being in the capability approach and beyond. Review of Social Economy, 63(2), 249-267. https://doi.org/10.1080/003467605001304 16

Guichard, J. (2018). Life design dialogue a new form of career and life design interventions. Journal of Counsellogy, 7, 267-304.

Hart, C. S. (2016). How do aspirations matter? Journal of Human Development and Capabilities, 17, 324-341. https://doi.org/10.1080/19452829.2016.1199540

Hart, C. S., \& Brando, N. (2018). A capability approach to children's well-being, agency and participatory rights in education. European Journal of Education, 53(3), 293-309. https://doi.org/10.1111/ ejed. 12284

Hart, C. S., Biggeri, M., \& Babic, B. (2014). Agency and participation in childhood and youth: International applications of the capability approach in schools and beyond. A\&C Black.

Heto, P. P. K., \& Indangasi, H. (2020). Mindset, heartset, and skillset. Journal of Interdisciplinary Studies in Education, 9(SI), 1-13. https://doi.org/10.32674/jise.v9iSI.2810

Hollywood, E., Egdell, V., McQuaid, R., \& Michel-Schertges, D. (2012). Methodological issues in operationalising the capability approach in empirical research: An example of cross-country research on youth unemployment in the EU. Social work and Society, 10(1)

Honneth, A. (1996). The struggle for recognition: The moral grammar of social conflicts. MIT Press.

Honneth, A. (2003). Redistribution as recognition: A response to Nancy Fraser. In N. Fraser \& A. Honneth (Eds.), Redistribution or recognition: A political-philosophical exchange, trans. Verso.

Honneth, A. (2014). The I in we: Studies in the theory of recognition. John Wiley \& Sons.

Joncas, J. A., \& Pilote, A. (2021). The role of guidance professionals in enhancing the capabilities of marginalized students: The case of indigenous women in Canada. International Journal for Educational and Vocational Guidance, 21(2), 405-427. https://doi.org/10.1007/s10775-021-09474-3

Krishnakumar, J. (2007). Going beyond functionings to capabilities: An econometric model to explain and estimate capabilities. Journal of Human Development, 8(1), 39-63.

Liu, Y. (2019). Exploring the application of inclusive design to the improvement of healthcare services. Unpublished doctoral dissertation, University of Cambridge.

Mojsoska-Blazevski, N., Petreski, M., \& Bojadziev, M. (2017). Youth survival in the labour market: Employment scarring in three transition economies. The Economic and Labour Relations Review, 28(2), 312-331. https://doi.org/10.1177/1035304617706424

Office of Government Economist, Financial Secretary's Office. (2018). Half-yearly Economic Report 2018. Hong Kong SAR Government. https://www.hkeconomy.gov.hk/en/pdf/er_18q2.pdf

Orton, M. (2011). Flourishing lives: The capabilities approach as a framework for new thinking about employment, work and welfare in the 21st century. Work, Employment and Society, 25(2), 352-360.

Pouyaud, J. (2016). For a psychosocial approach to decent work. Frontiers in Psychology, 7, 422. https:// doi.org/10.3389/fpsyg.2016.00422

Riessman, C. K. (2008). Narrative methods for the human sciences. Sage.

Robertson, P. J. (2015). Towards a capability approach to careers: Applying Amartya Sen's thinking to career guidance and development. International Journal for Educational and Vocational Guidance, 15(1), 75-88. https://doi.org/10.1007/s10775-014-9280-4

Robertson, P. J. (2018). Developing career capabilities in "NEET" young people: Experiences of participants in the Prince's Trust team programme. British Journal of Guidance \& Counselling, 46(6), 752-764. https://doi.org/10.1080/03069885.2018.1434130

Robertson, P. J., \& Egdell, V. (2018). A capability approach to career development: An introduction and implications for practice. Australian Journal of Career Development, 27(3), 119-126. https://doi. org/10.1177/1038416217704449

Robertson, P. J., \& Picard, F. (2021). An introduction to the special section on the Capability Approach to career guidance. International Journal for Educational and Vocational Guidance, 21(2), 395-404. https://doi.org/10.1007/s10775-021-09462-7 
Savickas, M. L. (1997). Career adaptability: An integrative construct for life-span, life-space theory. The Career Development Quarterly, 45(3), 247-259. https://doi.org/10.1002/j.2161-0045.1997.tb004 69. $\mathrm{x}$

Savickas, M. L. (2012). Life design: A paradigm for career intervention in the 21 st century. Journal of Counseling \& Development, 90(1), 13-19.

Savickas, M. L. (2015). Life designing with adults: Developmental individualization using biographical bricolage. In L. Nota \& J. Rossier (Eds.), Handbook of life design: From practice to theory and from theory to practice (pp. 135-150). Hogrefe Publishing.

Sen, A. (1993). Capability and well-being. In M. Nussbaum \& A. Sen (Eds.), The quality of life (pp. 30-54). Clarendon Press.

Sen, A. (2001). Development as freedom. Oxford University Press.

Sen, A. (2003). Inequality reexamined. Oxford Scholarship Online.

Sen, A. (2008). The economics of happiness and capability. In L. Bruni, F. Comim, \& M. Pugno (Eds.), Capabilities and happiness (pp. 16-27). Oxford University Press.

Sgaramella, T. M., \& Ferrari, L. (2019). Changing work in changing Contexts: New perspectives for job analysis in career counseling. Journal for Perspectives of Economic Political and Social Integration, 25(1), 27-43.

Stebbins, R. A. (2017). Between work and leisure: The common ground of two separate worlds. Routledge.

Su, X., \& Wong, V. (2020a). A research on workplace learning program informed by the expanded notion of work: A new perspective for youth career development (in Chinese). Youth Exploration, 225, 47-58.

Su, X., \& Wong, V. (2020b). Map of self-perceived growth for reviewing user journey and negotiating career transitions. African Journal of Career Development, 2(1), 1-9.

Su, X., Wong, V., \& To, S. M. (2020a). Factor structure of the Chinese career adapt-abilities scale in youth with a longer spell of status of not in education, employment, or training. Child \& Youth Services. https://doi.org/10.1080/0145935X.2020.1768843

Su, X., Wong, V., \& To, S. M. (2020b). Amotivation, career engagement, and the moderating role of career adaptability of youth not in education, employment, or training. Asia Pacific Career Development Journal, 3(2), 1-18.

Van den Brink, B., \& Owen, D. (2007). Recognition and power: Axel Honneth and the tradition of critical social theory. Cambridge University Press.

Vero, J., Bonvin, J.-M., Lambert, M., \& Moachon, E. (2012). Decoding the European dynamic employment security indicator through the lens of the capability approach. A Comparison of the United Kingdom and Sweden. Transfer: European Review of Labour and Research, 18(1), 55-67.

Vygotsky, L. S. (1978). Socio-cultural theory. Mind in Society, 6(3), 23-43.

Watts, A. G. (2015). Career education and the informal economies. In T. Hooley \& L. Barham (Eds.), Career development policy \& practice: The Tony Watts reader. Highflyers.

Wong, V. (2015). Youth transition to work in an age of uncertainty and insecurity: Towards an expanded notion of work for insight and innovation. Journal of Applied Youth Studies, 1(1), 21-41.

Wong, V., \& Yip, T. (2019). Promoting change: The "expanded notion of work" as a proactive response to the social justice issues in career development practice. In T. Hooley, R. Sultana, \& R. Thomsen (Eds.), Career guidance for emancipation: Reclaiming justice for the multitude (pp. 64-80). Routledge.

Wong, V., Pouyaud, J., Su, X., \& Yip, T.C.Y (2021). Incorporating the notion of decent work into the ENOW practice model for coping with challenges in career counseling and guidance. In V. CohenScali, (Ed.), Career counseling and guidance in the 21st century: Challenges and prospects (in French) (pp. 305-324). Dunod.

World Bank. (2019). World Bank Indicators. https://data.worldbank.org/indicator/SL.UEM.1524.ZS

Zimmermann, B. (2006). Pragmatism and the capability approach: Challenges in social theory and empirical research. European Journal of Social Theory, 9(4), 467-484.

Publisher's Note Springer Nature remains neutral with regard to jurisdictional claims in published maps and institutional affiliations. 